\title{
ベッセルピックのメカニズムと防止法
}

料日本紙パプ研究所大 澤 純 二

\section{Mechanism of Vessel Picking and Control Troubles in Printing Paper}

\author{
Junji Ohsawa \\ Japan Pulp and Paper Research Institute, Inc.
}

\begin{abstract}
Reduction of vessel picking tendency of hardwood pulps can be achieved by (1) reducing vessel content in a stock, (2) reducing the size of vessel elements, and (3) increasing vessel-tofiber bonding strength. Even though printing papers were made from the same beaten pulp, the vessel picking tendency changes considerably, depending on the paper machine, paper making conditions, and printing apparatus.

The most fundamental way to prevent vessel picking troubles is to eliminate large vessel elements from the surface of printing paper.

The first and the simplest way is the selection of suitable hardwood chip species which have small and slender vessel elements and conformable fibers. The second way is the removal of large and square-shaped vessel elements from hardwood pulps using hydrocyclones. The third and possibly the best way is the covering of vessel elements in paper surface with fibers using, for example, stratified sheet formation techniques.
\end{abstract}

Keywords: Vessel picking, Printing paper, Kraft cooking, Beating, Shape of vessel element, Bonding strength, Sheet formation, Filler distribution, Vessel element distribution, Stratified sheet formation.

\section{1.はじめに}

ベッセルピックとは印刷用紙の表面にある広葉樹道 管要素が印刷の際に版面のインキのタックによって剝 き取られる現象であり，印刷面の白抜けおよび版污れ の原因となる。ベッセルピックの原因は，まず大形の 道管が存在することであり，そして道管と緉維との結 合力が弱いときにトラブルが甚だしくなるものと考え られており，実際に工場でとられているペッセルピッ ク対策はおおむね次のようなものである。すなわら， (1)問題のあるチップの配合を減らし実質的に大形道管 の数を減らす。(2)表面サイズ剂染布量を增加すること などにより紙周との結合力を向上させる。(3)高浱度吒 解を行い道管を破片化する，ことなどである。これら の対策には原料チップの自由度が狭くなることや, 紙
品質が低下するなどの久陷を伴なうことは周知の通り である。

紙パ研では，このような久陷を避けつつ効果的にへ ッセルピックトラブルを防止しらるプロセスを確立す ることを目標に様々な検討を重ねてきたが，ここでは， この研究を通して得られた結果を整理し，基本的なへ ッセルピック対策のあり方について考察した。

\section{2. ベッセルピックに影響を及ばす}

\section{基本的因子}

印刷用紙の表面付近にある道管を図 1 亿摸式的に示 したが，印刷に際してピックされる道管の数は次のよ らな因子に支配されるものと考えられる。

（1）紙の表面付近にある道管の数，大きさ，形状

（2）道管と紙㬝との結合力 


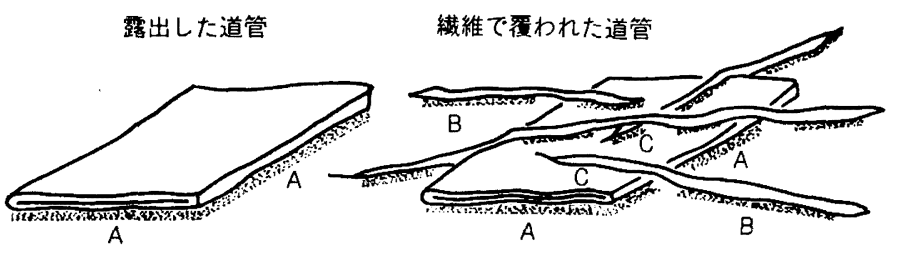

図 1 䋊の表面付近にある道管の結合モデル図
A : 道管とその下の紙層との結合
B : 道管上に乗っている織維と下の紙凮との結合
$\mathrm{C}$ : 道管とその上に乗っている㵶維との結合

（3）道管を被覆する織維の数と紙層との結合力

これら諸因子とベッセルピック数との基本的な関係 について検討するため, 様々な方法で調製したパルプ から標準手抄きシートを作製し，IGT 印刷試験に供し た。

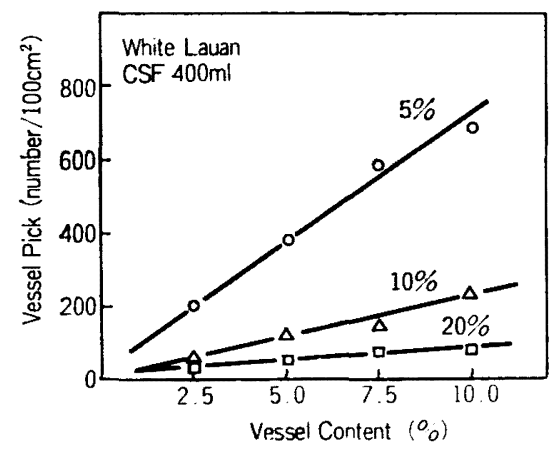

図 2 ラワンパルプの道管含有率, 叨解踮度とべ ッセルピック数との関係

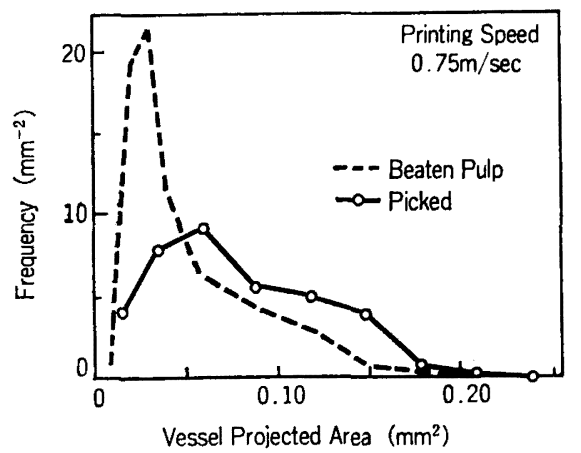

图 3 PFIミル叨解した MD パルプ中の道管 $(\cdots)$ と IG'T 印刷試験によってピックされた道 管（一）の面積分布（縦軸： $\Delta \mathrm{N} \% / \Delta \mathrm{A}$ $\mathrm{mm}^{2}$ )

\section{1 道管の数・大きさがヘッッルピック数に 影繁する}

フラットスクリーソ法によって分毞した道管フラク ションと織維および柔細胞のフラクションを再混合し て，道管含有率の異なるラワン BKP を得た。これを PFI ミル吒解したときの IGT 印刷の結果を図2に示

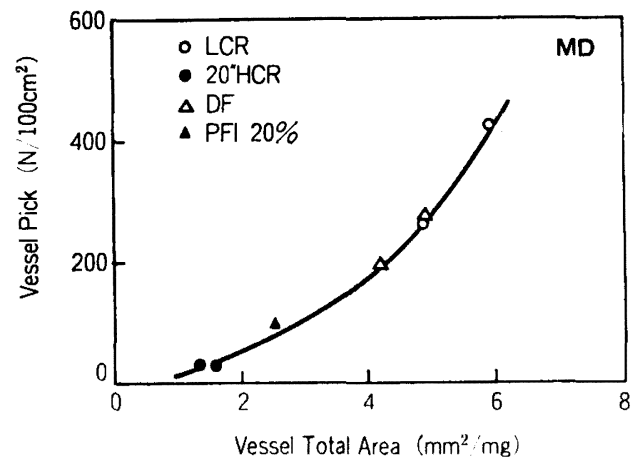

図 $4 \mathrm{MD}$ 叨解パルプ中の道管総面積とペッセル ピック数の関係

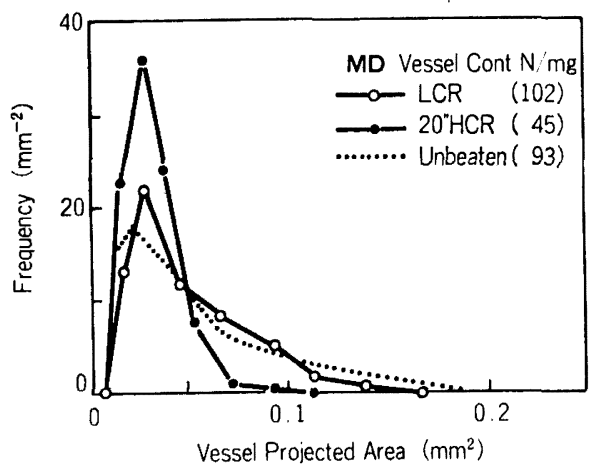

图 5 様々な吒解法による MD 吒解パルブ中の 道管面積分布（縦軸： $\Delta \mathrm{N} \% / \Delta \mathrm{Amm}^{2}$ ) 
す。それぞれの吒解濃度において，ベッセルピック数 は道管含有率にほぼ比例する。また，印刷によってピ ックされる道管は，もとのパルプに含まれるものと比 較して中形・大形道管の割合が多い（図 3)。道管の 数や大きさの総合的な効果として, 印解パルプ中の道 管の総面積が大きいほどベッセルピック数が多くなる といら関係があることが明らかとなった（図4）。

パルプを吒解するとピックされやすい中形・大形道 管は破壞, 細片化されるが, 低濃度印解より高濃度吒 解の方が破壞が著しく（図 5), 道管としての原型を 留めないものが多くなるために, 道管総面積减少の効 果は大きい。

\section{2 道管一城維間結合力はどのようにして 発現されるか}

多層構造をもつ紙を手抄きできるシートマシン （JPRI マルチヘッド）を考案し，ブナ吒解パルプの表 面にラワンの吒解パルブから単離した道管を散在させ た構造をもつ手抄き紙を調製した。ブナおよびラワン パルプの叨解条件をそれぞれ変えた組合せの手抄き紙 を印刷したところ，ブナパルプの吒解が進むほど，ま た吒解濃度が高いほと゚ペッセルピックは起きにくくな った (図6)。一方，ラワンの吒解程度や吒解濃度を 高くしても，単離したラワン道管のピック数はあまり 变化しなかった。したがって，吒解により道管一織維 間結合力が大さくなるのは，主として繊維のコンフォ マビリティが増大し，結合力が大きくなるためである と考えられる。

また，末吒解パルブから単離した道管フラクション を叨解してラワン，フナ，針葉樹パルプなどに一定量 ずつ混合したところ，ベッセルピック数はその組合せ により全く異なったことから，織維の形態も結合力に 大きく影賴していることが明らかである。

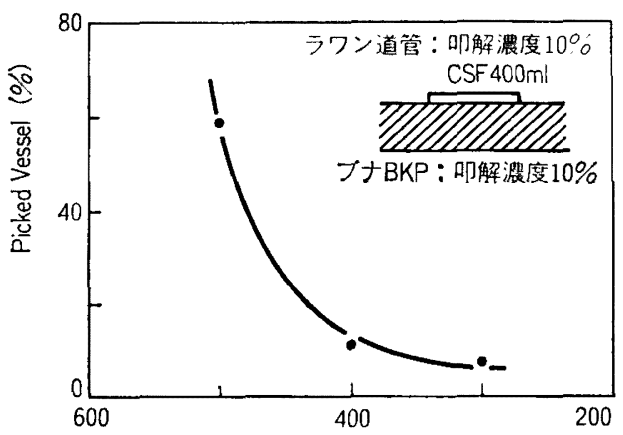

Freeness of Under Layer (ml)

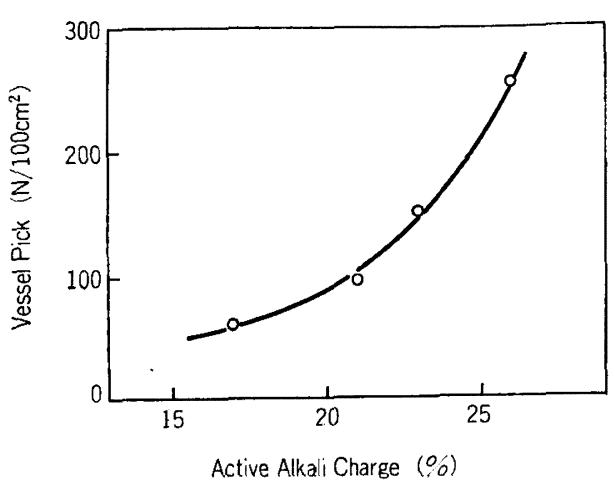

图 7 クラフト蒸解に和ける活性アルカリ添加率 とペッセルピック数（ラワン）

蒸解条件もベッセルピックに非常に影響しているこ とが分かった。ラワンチッブを活性アルカリ添加率を 変えて繁解し，漂白して得た品質の異なる BKP の手 抄き紙の印刷結果を図7に示す。活性アルカリ添加率 の高い条件ほどベッセルピック数が多くなることが明 らかであり,これは希アルカリ可溶へミセルロースの 含有量や重合度が低下することなど，化学組成の差に よって道管と織維の結合強度の差がもたらされたもの と推定される。

\section{3 印刷面の道管を被㜊する絩維のベッセル} ピック防止奻果は大きい

多層抄き用シートマシンで，表層をブナ，下層をラ ワンとする 2 層構造の紙を手抄さし，ラワン道管を覆 らプナパルプのペッセルピック防止効果について検討 した。図8に示すよらに，ブナ表層パルプの坪量がわ ずか $2 \mathrm{~g} / \mathrm{m}^{2}$ で, ブナパルプ $100 \%$ で抄いたのと同様 にベッセルピックがほとんど起きなくなった。このと

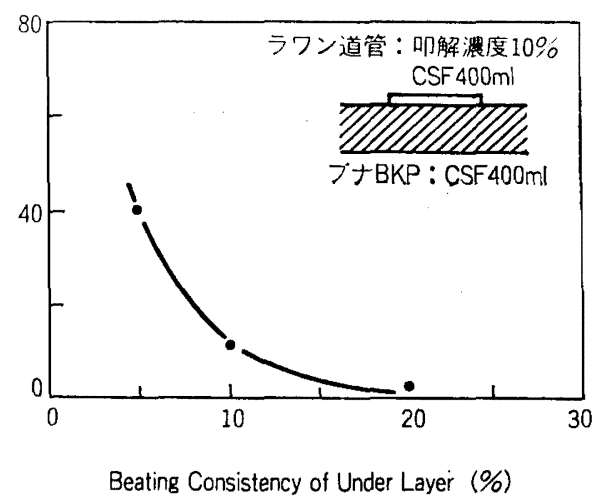

Beating Consistency of Under Layer (\%)

図 6 下層ブナパルプの印解度・吒解渡度と表層吒解ラワン道管のピック率 


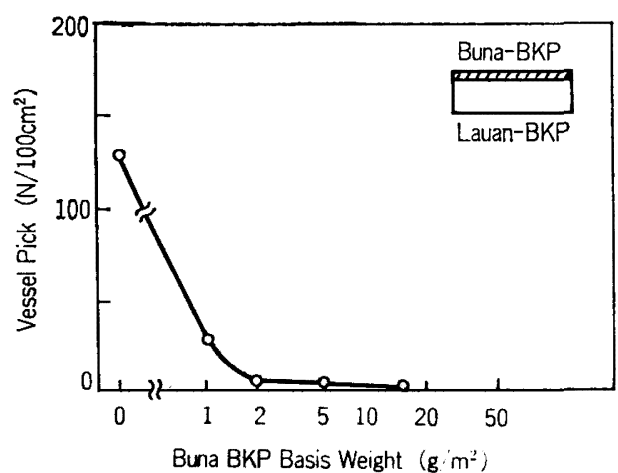

图 8 二層抄手抄き紙の印刷結果

表層: ブナ BKP, 下層 : ラワン BKP,

坪量: $60 \mathrm{~g} / \mathrm{m}^{2}$

横軸は表層プナパルブ仕込み量

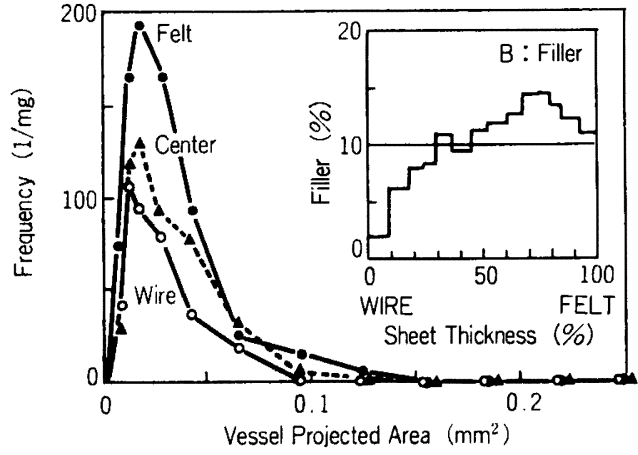

図 9 長網マシン抄造紙 $\left(67 \mathrm{~g} / \mathrm{m}^{2}\right)$ に扰ける道 管之填料のZ方向分布（緃軸： $\Delta \mathrm{Amm}^{2} /$ $\mathrm{mg} / \Delta \mathrm{Amm}^{2}$ )

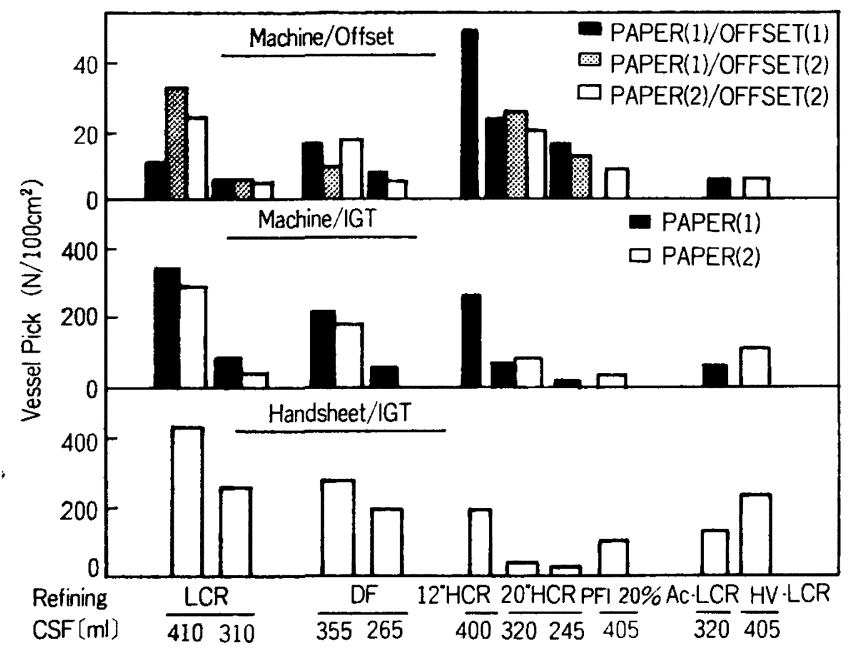

図10抄紙機と印刷機の組合せが各種 MD 叨解パルプのベッセルピック数に及ぼす影響 2 機のテストマシンにより抄造した上質紙拉よび標準手抄き紙を 2 台のオフセット 印刷機および IGT 型印刷試験機によって印刷した。

LCR, DF : 12 インチリファイナー（5％）およびデラックスファイナー（3.5\%） による低泧度吒解

$12{ }^{\prime \prime} \mathrm{HCR}, 20^{\prime \prime} \mathrm{HCR}, \mathrm{PFI} 20 \%$ ：12 扰よび 20 インチリフォイナー (22.5\%), PFI ミ ル $(20 \%)$ による高濃度吒解

Ac-LCR, HV-LCR：セントリクリーナー処理アクセプト側パルプ拈よび高粘度蒸 解パルプの LCR 
きラワン道管の表面は 4 〜 本の㵶維で覆われている にすぎない。このことから，紙層表面の道管を覆らわ ずかな本数の紻維が，ベッセルピック防止に極めて大 きな役割を果たすと言える。

\section{3. 紙層桠造・印刷条件とヘッセルピック}

標準手抄き紙をIGT 印刷することにより，パルプ の基本的なへッャセル゚ックの起きやすさは評価できる が，実際に印刷用紙を製造したとき，さらにそれを商 業印刷したときのベッセルピックは必ずしも予想でき るものではない。それは抄紙条件により紙層構造が変 化し，また印刷条件により䋺維間結合力が变化するた めであると考えられる。

\section{1 柢展 Z 方向の道管・场料分布によりヘッセル ピックの表覒差が生ずる}

長網マシン抄造の上質紙ではフェルト面からワイヤ 面にかけて道管含有率か隇少する傾向があり，ワイヤ 面の紙層単位重量当たりの道管総面積はフェルト面の 1/2kすぎなかった。また，道管一織維間結合を妨げ ると考えられる填料もフェルト面に多く分布していた （図 9)。したがって，道管の不均一な分布が堚料分布 とあいまって，印刷に際しフェルト面のペッセルピッ クを多くしている原因の一つと考えられる。

一方，ツインワイヤマシン（Bel Baie II）抄造紙 では，両面付近の道管含有率は紙層中央部の $1 / 2$ にす ぎず，長網マシン抄造紙よりもベッセルピックが発生 しにくいと予想される。

\section{2 抄弤条件や印刷機によりヘッセルピック} 傾向は大きく異なる

南洋産広葉樹混合材パルブ (M D-B K P : 高粘度蒸 解したHV，拉よびセントリクリーナー処理によるア
クセプト側パルプ Ac を含む) を12，20インチリフ フイナー，デラックスファイナー，PFI ミルなどの吒 解機を使用し，吒解漫度，フリーネスを变えた条件で 吒解し，抄紙した。2 台のテストマシンで抄紙した上 質紙の 2 台のオフセット印刷機による印刷結果を，同 し上質紙扰よび同じ解パルプからの標準手抄き紙の IGT 印刷結果と対比乙て図10 亿示す。

標準手抄き紙の IGT 印刷試験結果と比較すると， テストマシン抄造上質紙を IGT 印刷した場合，吒解 パルプのフリーネスの影響が大きく，それぞれの吒解 機では低フリーネスまで吒解することによりベッセル ピックが大幅に減少することが分かる。さらに，これ らの上質紙をオフセット印刷したところ，IGT 印刷で ピック数が少なかった高濃度吒解 (HCR) パルプでは ピック数が非常に多くなるのに比へ，低濃度吒解パル プで (LCR) は比較的安定しているため，LCR の方が 相対的に有利になる点が特に注目に値する。

種々の検討をしたところ，LCR パルプに比へ吒解 による織維の変形が大きい $\mathrm{HCR}$ パルプでは，抄紙工 程に㧊ける填料の内添，カレンダー掛けや，印刷時の 湿し水の影響を大きく受け，ベッセルピック数を増加 させることが明らかになった。

\section{4. より汎用性のあるへッッセピック} 対策を求めて

以上述べてきたように，ヘッセルピックトラブルを 軽減するためには道管の数を減少すること，道管を小 さくすること，䊼維間結合力の大きいパルプ䄉維を選 択することが基本的に重要である。一方，全く同じ吒 解パルブであっても抄紙・印刷条件によってベッセル ピックの起きやすさが大きく変わりらることも明らか
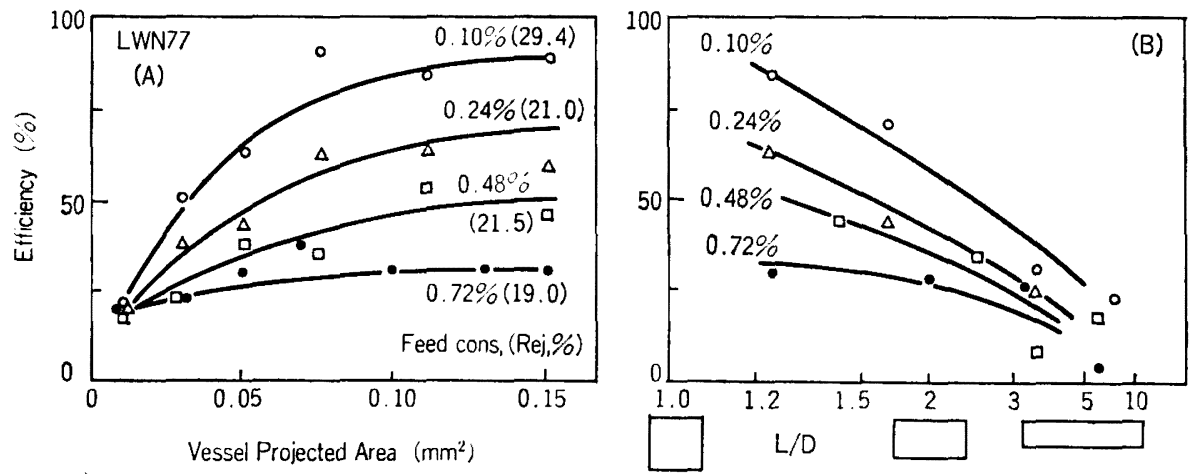

图11 セントリクリーナー処理港度と道管分離効率

(A) 道管面積の影響

(B) 道管形状（長辺長さ L/短辺長さD）の影響 
であり，品質の劣る広葉樹パルブを使用するかぎり， 従来通りの対策ではベッセルピックトラブルの不安は 根本的にぬぐいさることのできない問題である。

最も基本的なベッセルピック防止方法は，ピックさ れやすい道管を印刷面から締め出すことである。その ためには製紙工程のうち次の 3 つの段階, すなわち, (1)チップ，(2)パルプ，そして(3)抄紙の段階で対策をと ることがでさる。

初めのチップの段階で樹種を選択することは，ピッ クされやすい大形道管を排除すると同時に結合性のよ い䄉維を選択することでもあり，極めて有効ではある が沉用性をもつ対策とはなり得ない。

次のパルプの段階で道管を瀻維から分離除去するた めに種々の分離法を検討したところ，液体サイクロン (セントリクリーナー600) 処理が最も効率的である ことが分かった。图11に示すように，ラワン BKP の低漕度スラリーを液体サイクロン処理すると，ピッ クされやすい大形の道管がリジェクト側に効率良く分 離される。たたし，細長い道管は大形であっても分離
されにくい傾向をもつため，南洋産混合材パルプの道 管の分離効率はラワンパルプに比べると非常に劣るが, それでも図10に示したように，実際のペッセルピッ ク防止効果は極めて大きい。大形道管を完全に分離除 去するのは不可能に近いが，有力なべッセルピック軽 隇手段である。

最後の抄紙の段階で紙表面から道管を排除する方法 は2.3項で述べたよらに極めて効果的である。ベッセ ルピックを起こしやすいパルプを主原料とする紙であ っても，適切な紙層構造，すなわち印刷面となる紙表 面を $2 \mathrm{~g} / \mathrm{m}^{2}$ 以上のペッセルピックを起こさない良質 のパルプで覆ら構造をもつ紙を製造することにより， ペッセルピックはほぼ完全に防止でさる。その様な紙 の製造には，抄き合わせによらない，単一へッドボッ クスによる多層抄紙技術が適しており，しか子従来の ベッセルピック対策のもつ, 使用可能樹種の制約, 紙 品質の低下，あるいはパルプ調成工程の複㵶化などの 欠点を伴わず, ベッセルピックトラブルの発生しない 印刷用紙の製造が可能である。 